\title{
SIMPLIFIKASI RITUAL HARAI DAN DIMENSI KULTURAL HOFSTEDE DALAM IKLAN FORTE VERSI SUMO
}

\section{Simplification of Harai Rituals and Cultural Hofstede Dimensions in Ads Forte Sumo Version}

\author{
Bernard Realino Danu Kristianto ${ }^{1}$, Rustono Farady Marta ${ }^{2}$ \\ Ilmu Komunikasi, Universitas Bunda Mulia \\ Magister Ilmu Komunikasi, Universitas Bunda Mulia
}

Diterima 20 Januari 2019/ Disetujui 29 Maret 2019

\begin{abstract}
This research is entitled Simplification of Hit Ritual and Hofstede Cultural Dimensions in Sumo Version of Forte Ads. This study aims to understand the Harai Rituals in simplified Sumo rituals and Hofstede's cultural dimensions in FORTE cigarette product advertisements. The FORTE cigarette product is relatively new in the Indonesian market. This cigarette product originating from a Japanese company was launched by a local Indonesian company, PT Djarum. But in the advertisement, the product featured Sumo wrestlers who were squeezed by a frame which later revealed mighty tiny writing as the main FORTE cigarette slogan. In the discussion, it will be explained how Hofstede's dimensions of cultural cross are presented through the overall appearance of Forte's cigarette advertisements and products. The researcher concluded that the audio-visual work of Forte cigarette products in the form of advertisements was a simplification of the ritual of the Sumo sport for the purpose of product promotion and the duration of the ad itself. The Japanese cultural identity that appears in FORTE's cigarette advertisements through Sumo sports has the complexity of historical cultural dimensions which are full of meaning and philosophy.
\end{abstract}

Keywords; Simplification, Harai, ritual, cultural, Hofstede, Forte.

\begin{abstract}
ABSTRAK
Penelitian ini berjudul Simplifikasi Ritual Harai dan Dimensi Kultural Hofstede dalam Iklan Forte Versi Sumo. Penelitian ini bertujuan memahami Ritual Harai dalam ritual Sumo yang tersimplifikasi serta dimensi budaya Hofstede dalam iklan produk rokok FORTE. Adapun produk rokok FORTE ini tergolong baru di pasar Indonesia. Produk rokok yang berasal dari perusahaan Jepang ini diluncurkan oleh perusahaan lokal Indonesia, PT Djarum. Namun dalam penayangan iklannya, produk ini menampilkan pegulat Sumo yang terhimpit oleh frame yang kemudian memunculkan tulisan mighty tiny sebagai slogan utama rokok FORTE tersebut. Dalam pembahasan, akan dipaparkan bagaimana dimensi-dimensi lintas kultural Geert Hofstede dipaparkan melalui penampilan keseluruhan iklan dan produk rokok Forte. Peneliti mengambil kesimpulan bahwa karya audio visual produk rokok Forte yang berbentuk iklan merupakan simplifikasi ritual harai dalam olahraga Sumo demi tujuan promosi produk dan durasi iklan itu sendiri. Identitas budaya Jepang yang tampil dalam iklan rokok FORTE melalui olah raga Sumo memiliki kompleksitas dimensi kultural historis yang sarat makna dan filosofi.
\end{abstract}

Kata kunci; Simplifikasi, ritual, Harai, kultural, Hofstede, Forte.

*Korespondensi Penulis:

E-mail: bkristanto@bundamulia.ac.id,rmarta@bundamulia.ac.id 


\section{PENDAHULUAN}

Di era modern ini, bagi sebuah perusahaan, strategi peningkatan pemasaran dan brand awareness dalam bentuk iklan sangat penting dilakukan untuk mempromosikan produk-produknya kepada masyarakat luas. Televisi sebagai media periklanan relatif efektif digunakan oleh perusahaan untuk memasarkan produknya. Program acara televisi yang ditayangkan menjadi pemikat pemirsa, sehingga menjadi sarana yang bagus bagi perusahaan untuk menyisipkan iklan produknya pada acara televisi tersebut, yang memang dilakukan oleh televisi sebagai jeda komersial, disediakan oleh televisi untuk slot tayangan iklan di selasela tayangan suatu program acara, jika iklan produk ditayangkan di televisi maka kemungkinan besar iklan tersebut ditonton oleh semua kalangan masyarakat. Iklan merupakan suatu media yang berisikan pesanpesan atau info mengenai suatu produk barang atau jasa yang ditawarkan kepada konsumen.

Dalam komunikasi periklanan, iklan tidak hanya menggunakan bahasa sebagai alatnya, tetapi juga alat komunikasi lainnya seperti gambar dengan citra bergerak (motion picture), warna dan bunyi-bunyi dimana perpaduan keseluruhan akan menghasilkan komunikasi periklanan yang efektif (Mulyana, 2007:68). Pun demikian siaran iklan dikatakan oleh Undang-Undang Nomor 32 Tahun 2002 tentang Penyiaran sebagai siaran informasi yang bersifat komersial dan layanan masyarakat tentang tersedianya jasa, barang, dan gagasan yang dapat dimanfaatkan oleh khalayak dengan atau tanpa imbalan kepada lembaga penyiaran yang bersangkutan (pasal 1 ayat 5). Iklan sendiri merupakan salah satu faktor kebudayaan paling penting yang mencetak dan merefleksikan kehidupan manusia saat ini. Iklan ada di mana-mana, sebagai bagian tak terelakkan dari kehidupan setiap orang. Bahkan, seandainya seseorang tidak membaca surat kabar atau menonton televisi, berbagai imaji yang dipasang di lingkungan urban sekitar kita merupakan hal yang tidak terhindarkan. Dengan menjalari semua media, dan tidak dibatasi pada siapa pun, periklanan membentuk sebuah suprastruktur luas dengan eksistensi yang tampak otonom dan disertai pengaruh yang sangat besar.

Adalah sifat iklan yang ada di manamana (ubiquitous) serta ketahanannya sebagai 'bentuk' yang dapat dikenali inilah yang mengindikasikan signifikansi periklanan, terlepas dari fakta fungsinya dalam media teknis yang berbeda dan juga terlepas dari 'muatan' yang berbeda (yaitu berbagai pesan yang berbeda tentang berbagai produk yang berbeda). Periklanan memiliki sebuah fungsi, yakni menjual benda-benda kepada konsumen. Namun, periklanan memiliki fungsi lainnya dalam banyak hal, menggantikan fungsi yang secara tradisional dipenuhi oleh seni dan agama. Periklanan menciptakan strukturstruktur makna (Williamson, 2007: 1-2). Iklan itu sendiri merupakan suatu simbol yang divisualisasikan melalui berbagai aspek tanda komunikasi dan tersusun dalam struktur teks iklan. Tanda-tanda yang terdapat dalam suatu struktur teks iklan merupakan satu kesatuan sistem tanda yang terdiri dari tanda-tanda verbal dan non verbal berupa katakata, warna ataupun gambar serta memiliki makna tertentu yang disesuaikan dengan kepentingan produk yang akan dipasarkan atau yang akan diinformasikan. Pengaruh iklan yang begitu besar terhadap alam bawah sadar khalayak ini tentunya bisa dimanfaatkan pengiklan untuk berbagai tujuan, mulai dari mengenalkan produk, meningkatkan penjualan sampai memperkuat citra produk atau perusahaan. Iklan televisi menarik bagi konsumen karena keunggulannya menyajikan audio dan visual secara bersamaan. Televisi sebagai media periklanan, merupakan salah satu media yang paling mudah untuk mempromosikan produk barang dan jasa kepada masyarakat. Televisi sebagai media iklan memberi dukungan yang besar bagi perusahaan dalam mempromosikan produk - produk yang pada akhirnya dapat meningkatkan penjualan untuk memperoleh keuntungan perusahaan. Banyaknya bentuk dan jenis iklan di televisi, menuntut tim kreatif dan agensi untuk selalu mencari ide dalam menciptakan kemasan iklan yang mudah diingat, memberikan respon yang positif atas citra atau image produk yang dipromosikan atau disampaikan kepada khalayak, karena sebagian besar masyarakat khususnya masyarakat Indonesia, televisi sudah merupakan bagian dari gaya hidup untuk 
memperoleh informasi - informasi. Kreatifitas kemasan iklan tentunya dapat menjadi strategi efektif dalam usaha promosi tersebut di atas. Seperti halnya pada kemunculan iklan rokok di televisi dewasa ini.

Berbicara tentang kreatifitas kemasan iklan rokok yang ditampilkan di televisi, pemerintah Indonesia memiliki regulasi terhadap pelarangan visualisasi rokok itu sendiri. Tidak hanya produk rokok, iklan produk seperti alat kontrasepsi dan iklan obatobatan selalu menimbulkan kontroversi di kalangan masyarakat. Menurut Bing Bedjo Tanudjaja, terdapat tiga produk dalam dunia periklanan yang selalu menimbulkan kontroversi, yaitu: alkohol, rokok dan kondom (Tanudjaja: 2007). Dunia praktisi periklanan menyebutnya sebagai produk AKROBAT, akronim dari: Alkohol, Kondom, Rokok, dan Obat-obatan. Produk-produk tersebut selalu mendapatkan 'perlakuan khusus'. Khusus untuk rokok, WHO, organisasi kesehatan dunia yang bernaung dibawah payung Perserikatan Bangsa Bangsa telah menghimbau supaya perusahaan-perusahaan tidak lagi memanfaatkan dana dari produsenprodusen rokok bagi keperluan kegiatan sponsorship.

Undang-Undang Penyiaran Nomor 32 Tahun 2002 mencantumkan iklan alkohol dan rokok dalam pasal 46 ayat $3 b$ dan $3 c$ yang melarang promosi minuman keras, bahan/zat adiktif, dan promosi rokok yang memperagakan wujud rokok. Sedangkan mengenai obat-obatan diatur dalam pasal 36 ayat $5 \mathrm{~b}$, bahwa isi siaran dilarang menonjolkan penyalahgunaan narkotika dan obat terlarang. Adapun iklan kondom tidak disebutkan dalam undang-undang ini. Selain itu, terbit juga PP No. 19 Tahun 2003 tentang Pengamanan Rokok bagi Kesehatan, yang berisi: (1) rokok wajib diperiksa kadar kandungan tar-nikotin oleh lembaga yang terakreditasi; dan wajib diinformasikan pada bungkus rokok, (2) wajib mencantumkan peringatan kesehatan : merokok dapat menyebabkan kanker, serangan jantung, impotensi dan gangguan kehamilan dan janin, (3) iklan pada media elektronik hanya diperbolehkan pada pukul 21.30 sampai dengan pukul 05.00, dan (4) kawasan tanpa rokok di tempat-tempat umum, sarana kesehatan, tempat kerja, sarana belajar mengajar, arena kegiatan anak, tempat ibadah, dan angkutan umum. Akhir-akhir ini selain "PERINGATAN: MEROKOK MEMBUNUHMU" yang disertai dengan simbol "18+", beberapa peringatan lain banyak dicantumkan pada kemasan bungkus rokok seperti halnya "MEROKOK MENYEBABKAN KANKER MULUT", "MEROKOK DAPAT MENYEBABKAN KANKER PARU-PARU DAN BRONKITIS KRONIS", di mana semua peringatan tersebut disertai dengan visualisasi penyakit yang terjadi pada tubuh manusia.

Dengan pelarangan wujud rokok dan peran dalam sponsorship dari pemerintah Indonesia dan dunia internasional tersebut di atas, insan periklanan yang dibayar secara khusus oleh produsen atau pengiklan tentunya harus memeras otak dan keringat supaya tujuan dari pemasarannya dapat tercapai secara efektif. Maka dengan demikian, pihak produsen akan mencari cara kreatif tanpa menyalahi peraturan-peraturan yang berlaku. Bahkan, meskipun tidak terdapat peraturan yang menyatakan bahwa setiap iklan produk rokok juga harus mencantumkan informasi seperti halnya yang termaktub dalam PP No. 19 Tahun 2003 (peringatan kesehatan pada bungkus rokok), hal ini menjadi strategi kreatif pengiklan dalam visualisasi iklan produknya. Sehingga meskipun dalam visualisasi iklan tidak terdapat wujud rokok itu sendiri atau bahkan ide cerita yang terkandung di dalamnya tidak berhubungan sama sekali dengan produk rokok, ironisnya informasi seperti halnya pada bungkus rokok tentang bahaya kesehatan karena merokok tadi justru menginformasikan bahwa iklan tersebut merupakan iklan produk rokok.

Seperti halnya yang tervisualisasi dalam iklan produk rokok bermerk FORTE. Produk rokok FORTE ini tergolong baru di pasaran Indonesia, sekiranya iklan yang masuk ke stasiun televisi baru tayang di pertengahan bulan Desember 2017. Meskipun demikian iklan yang tampil di beberapa stasiun televisi nasional ini tergolong tinggi frekuensi tayangannya. Dari pengamatan penulis, dalam durasi 2 jam sebuah film yang tayang (beserta iklan-iklannya) di sebuah stasiun televisi nasional, setidaknya terdapat 2 kali penayangan iklan rokok FORTE di setiap break iklan. Bila diakumulasi dalam durasi 2 jam terdapat 6 kali break iklan, maka terdapat 
kurang lebih 12-15 kali penayangan iklan rokok FORTE. Belum lagi program-program yang menyusul di belakangnya berkaitan dengan olahraga, iklan rokok FORTE tampaknya mendapat 'jatah' slot yang signifikan pula. Nampaknya dengan durasi iklan produk rokok FORTE yang berdurasi 15 detik; yang mana durasi tersebut merupakan setengah dari durasi iklan produk pada umumnya, memberi gerak bagi pengiklan untuk memaksimalkan frekuensi penayangannya.

Adapun iklan rokok FORTE tersebut tampil diawali oleh gambar kemunculan seorang pegulat Sumo khas Jepang yang sedang melakukan gerakan ritual mengatupkan kedua telapak tangan, kemudian dilanjutkan dengan gerakan 'kuda-kuda'. Elemen grafis ditambahkan setelah pegulat tersebut selesai melakukan gerakan 'kuda-kuda', dengan menampilkan frame persegi panjang yang bergerak dan berubah bentuk dari besar ke kecil seolah menghimpit pegulat tersebut hingga badan pegulat tersebut terdistorsi karena himpitan frame. Dalam ekspresi kesusahan, pegulat tersebut berusaha membebaskan diri dari himpitan frame, yang kemudian disertai tulisan "mighty tiny" dengan frame berisi pegulat yang terhimpit sebagai huruf I pada kata "mighty tiny" tersebut. Grafis berikutnya muncul dengan tulisan di tengah layar kata charcoal filter, kata FORTE di bawahnya dituliskan dengan ukuran font yang besar sehingga mendominasi point of interest layar, diikuti kata "original" di bawahnya. Grafis lain tertera bertuliskan "new" di pojok samping kiri atas, 18+ di pojok kanan bawah serta peringatan "merokok membunuhmu" di bagian bawah layar dan gambar perokok seperti halnya pada kemasan produk rokok. Dari elemen suara, hanya terdapat instrumen alat musik kato (alat musik petik dari jepang) di bagian awal klip, diikuti instrumen perkusi dengan beat cepat hingga di akhir klip. Juga terdapat narasi yang mengucapkan kata "mighty tiny" dan "FORTE".

Yang menarik dari iklan ini adalah elemen budaya Jepang yang ditampilkan dalam visualisasi iklan rokok FORTE tersebut. Pegulat Sumo disertai instrumen musik khas yang menjadi ikon budaya Jepang ditampilkan sebagai informasi yang menurut penulis sebut sebagai gimmick untuk memancing rasa penasaran penonton untuk tahu lebih lanjut mengenai produk rokok baru ini. Forte merupakan produk portofolio SPM (Sigaret Putih Mesin) pertama dari Group Djarum untuk pasar di Indonesia dengan keunggulan ukuran diameter dan panjang batang yang kecil. Pertama kali diluncurkan di Jepang pada Juni 2016, Forte seakan memasuki segmen SPM Mini yang untuk pasar Jepang sendiri masih dikuasai oleh Hope, yang diproduksi oleh Japan Tobacco. Produk ini untuk pasar Jepang dikategorikan sebagai little mini cigars, dalam artian rokok ini di Jepang terhitung sebagai cerutu mini filter, bukan terhitung sebagai rokok putih layaknya di Indonesia. Hal ini dikarenakan kertas pada rokok ini dibuat dengan menggunakan tembakau, yang diproses menggunakan sisa debu atau limbah dari tembakau itu sendiri, yang di luar negeri terhitung sebagai little mini cigars. Kertas yang digunakan pada produk rokok Forte ini disebut sebagai "Reconstituted Tobacco Sheet", atau kertas Tembakau Recon. Mengingat Forte memiliki tingkat antusias yang tinggi di Jepang, maka pada akhirnya Group Djarum mulai berani meluncurkan Forte di Indonesia pada pertengahan bulan Desember tahun 2017.

Strategi jitu penjualan oleh Group Djarum ini tampaknya bertujuan untuk mengimbangi kompetitor, dalam hal ini Gudang Garam Tbk. Seperti dilansir oleh situs Okezone Finance pada 8 Agustus 2017, "PT Gudang Garam Tbk (GGRM) dipastikan akan meraup banyak untung setelah proses divestasi saham entitas anak, yaitu PT Karya Dibya Mahardhika (KDM) dan PT Surya Mustika Nusantara (SMN) oleh Japan Tobacco. Tidak hanya mengantongi dana segar hingga lebih dari Rp8 triliun, beban keuangan emiten dengan kode GGRM ini akan berkurang signifikan. Pasalnya, Japan Tobacco secara otomatis akan mengambil alih kewajiban yang menyertai dua anak usaha."

Geert Hofstede menganalisis budaya dari beberapa bangsa dan mengelompokkannya ke dalam beberapa dimensi. Dimensi budaya menurut Hofstede adalah perbandingan budaya mengandaikan bahwa ada sesuatu yang harus dibandingkan - 
bahwa setiap budaya sebenarnya tidaklah begitu unik, bahwa setiap budaya yang paralel dengan kebudayaan lain tidak memiliki makna yang begitu berarti.

Dimensi pertama, power Distance atau jarak kekuasaan adalah sejauh mana anggota dari suatu organisasi atau lembaga yang berada dalam posisi yang kurang kuat menerima dan berharap kekuasaan didistribusikan secara tidak merata. Dimensi budaya yang mendukung jarak kekuasaan rendah (Small Power Distance) mengharapkan dan menerima hubungan kekuasaan secara lebih konsultatif atau demokratis. Orang berhubungan satu sama lain terlepas dari posisi formalitas mereka. Bawahan merasa lebih nyaman serta menuntut hak untuk berkontribusi dalam pengambilan keputusan (Hofstede, 2010: 61).

Dimensi Kedua, Uncertainty

Avoidance adalah bentuk toleransi masyarakat untuk ketidakpastian dan ambiguitas. Hal ini menggambarkan sejauh mana anggota organisasi atau lembaga berusaha untuk mengatasi perasaan cemas dan mengurangi ketidakpastian yang mereka hadapi. Pemahaman ini menjelaskan bahwa uncertainty avoidance bukan berarti penghindaran risiko.

Dimensi ketiga Individualism dan Collectivism, adalah sejauh mana individu diintegrasikan ke dalam organisasi atau lembaga tersebut. Dimensi keempat, Masculinity berkaitan dengan nilai perbedaan gender dalam masyarakat, atau distribusi peran emosional antara gender yang berbeda.

Dimensi kelima berhubungan dengan budaya masyarakat yang berorientasi jangka panjang (long term orientation) lebih mementingkan masa depan. Mereka mendorong nilai-nilai pragmatis berorientasi pada penghargaan, termasuk ketekunan, tabungan dan kapasitas adaptasi. Dimensi Terakhir yaitu Kesenangan (indulgence) mengarah kepada lingkungan sosial yang mengijinkan gratifikasi sebagai nafsu manusiawi yang alamiah terkait dengan menikmati hidup. Pengekangan (restraint) mengarah kepada lingkungan sosial yang mengontrol gratifikasi dari kebutuhan dan peraturan-peraturan dengan cara norma sosial yang tegas.
Menilik kemunculan rokok asli Jepang yang diikuti dengan tayangan iklan bertemakan olahraga Sumo, mengingat budaya Jepang dan segala ritual dan tradisinya sarat akan makna dan filosofinya, maka yang menjadi fokus permasalahan dalam penelitian ini adalah, bagaimana simplifikasi ritual harai dan dimensi budaya Hofstede dalam iklan FORTE versi Sumo.

\section{METODE PENELITIAN}

Menurut George Ritzer, paradigma sendiri secara sederhana dipahami sebagai pandangan mendasar dari suatu disiplin ilmu tentang apa yang menjadi pokok persoalan yang semestinya dipelajari oleh ilmu yang bersangkutan (Purba, 2006: 16). Masingmasing paradigma tentu mengasumsikan interpretasi yang berbeda mengenai realitas, perilaku manusia, budaya dan komunikasi (Martin \& Thomas, 2007: 47). Beberapa ahli komunikasi percaya bahwa ada sebuah realitas eksternal yang dapat diukur dan dipelajari, sementara yang lain percaya bahwa realitas dapat dimengerti hanya hidup dan dialami oleh individu. Pendek kata, kepercayaan dan asumsi tentang realitas mempengaruhi metode dan penemuan penelitian kemudian juga mempengaruhi apa yang secara tepat kita ketahui sebagai komuniksi antarbudaya. Selanjutnya, kita dapat mengidentifikasi 3 pendekatan yang masing-masing memberikan karaktersitik bagi budaya dan komunikasi. Ketiga pendekatan ini melibatkan sebuah campuran displin ilmu dan merefleksikan pandangan yang berbeda serta asumsi tntang realitas, perilaku manusia, dan cara untuk mempelajari budaya dan komunikasi. Tiga pendekatan yang mempelajari komunikasi antarbudaya adalah 1. pendekatan ilmu sosial (fungsional), 2. pendekatan interpretif, 3. pendekatan kritis. Masing-masing memberikan cara yang unik untuk memahami hubungan anatara kebudayaan dan komunikasi tetapi msing-masing memiliki keterbatasan. (Martin \& Thomas, 2007: 49).

Adapun paradigma yang akan digunakan dalam penelitian ini adalah paradigma interpretif. Para peneliti dengan pendekatan ini berasumsi pendekatan ini adalah tidak hanya realitas eksternal dari manusia tapi juga manusia mengkonstruksikan 
realitas. Mereka juga percaya bahwa pengalaman manusia, termasuk komunikasi, bersifat subjektif dan perilaku manusia tidak ada ditetapkan sebelumnya maupun diprediksi. Tujuan dari penelitian komunikasi antarbudaya dengan pendekatan ini adalah untuk mengerti dan menjelaskan perilaku manusia dan memprediksi tidak menjadi tujuan ( Martin \& Thomas, 2007: 56). Jadi, dengan pendekatan ini, penelitian akan fokus pada pengertian akan suatu fenomena secara subjektif dari dalam sebuah komunitas budaya tertentu, dan inilah yang disebut penelitian "'emik'. Penelitian ini

\section{HASIL DAN PEMBAHASAN}

Adapun olah raga Sumo telah hidup berabad-abad lamanya. Sumo berasal dari kata sumai, dari kata sumafu, yang digunakan hingga abad ke-10 lalu berubah menjadi Sumou. Mai selain memiliki arti tarian juga berarti bertarung. Sumai berasal dari kata $s u$ no mai yang artinya tarian tanpa kostum (Cuyler, 1979: 32).

Menurut buku sejarah Jepang, Nihon Shoki -buku sejarah dan mitologi Jepang yang berasal dari zaman Nara-, disebutkan bahwa Sumo berawal di zaman Nara periode 646794, namun Sumo diperkirakan sudah muncul sebagi ritual kepercayaan Shinto sejak zaman Yamato yaitu sekitar tahun 250-552 Masehi. Hal ini diperkuat dengan penemuan haniwa (arca kecil yang terbuat dari terakota (tembikar yang tidak dilapisi glasir, dibuat dari tanah liat, dibakar sehingga warnanya merah kecoklatan) biasanya tersusun melingkari permukaan kubur) berbentuk Sumo pada ekskavasi zaman Yamato yang banyak ditemukan kubur kuno (Cuyler, 1979: 21).

Awalnya Sumo merupakan pelayanan keagamaan yang berhubungan dengan perayaan masa panen padi, dan seiring berjalannya waktu digunakan untuk pemujaan terhadap Tuhan untuk meminta perlindungan bagi negaranya, perayaan tersebut dinamakan sumai no sechie. Pada zaman Kamakura olahraga Sumo lebih banyak digunakan untuk melatih para samurai dan digunakan sebagai alat politik. Cahyo dan Mael (2017:213) menyebutkan empat golongan masyarakat di Jepang pada jaman Kamakura, dimana kasta rendah dimulai dari golongan shounin akan mencoba untuk menjelaskan pola-pola atau aturan-aturan di mana individu mengikuti pada konteks yang spesifik. Penelitian akan cenderung jadi lebih tertarik untuk menjelaskan perilaku kultural dari suatu komunitas daripada melakukan perbandingan lintas budaya (Martin \& Thomas, 2007: 57). Sebagai metode penelitian, observasi partisipan dan studi lapangan terhadap produk rokok FORTE juga penulis lakukan sebagai pendukung pemahaman dan perspektif interpretif dalam penelitian ini.

(pedagang) dan kouin (pegawai), kemudian golongan noumin (petani) serta tertinggi dipegang oleh bushi (prajurit atau samurai). Oleh karena itu, di era Kamakura sekitar tahun 1192-1333 Jepang mengagungkan ajaran Bushido, yaitu daya juang menjunjung harga diri tinggi sebagai etik dan falsafah hidup golongan kelas atas di masyarakat. (Suliyati, 2013:1-2)

Di zaman Muromachi, justru Sumo berkembang menjadi Kanjin-Sumo, karena bertugas sebagai abdi penjaga keluarga Ashikaga (Sari, 2016:23). Selain itu, Sumo diangkat menjadi olah raga profesional, dan digunakan sebagai acara penggalangan dana untuk memperbaiki kuil. Jika menarik ke sisi historis, pada era Nara kekasiaran Jepang justru didominasi oleh kaisar wanita seperti disebutkan Hartono (2007:7) bahwa tercatat tiga nama kaisar Wanita di era Nara, yaitu Empress Gensho (715-748), Empress Koken (749-763), dan Empress Shotoku (764-793). Jabatan terakhir imperium Jepang dipimpin oleh wanita adalah Empress Gosakuremachi (1762-1770) dalam zaman Edo.

Selain itu penjelasan lain muncul juga dalam Kojiki, buku sejarah tertua Jepang yang dibuat pada tahun 712 , yang menjelaskan tentang mitologi klan Yamato. Di dalam Kojiki disebutkan bahwa dewa Takemikazuchi dan dewa Takeminakata bertanding Sumo di sepanjang laut Jepang untuk memperebutkan daratan Jepang. Alasan pemilihan gulat karena pada masa awalnya gulat dipandang sebagai cara untuk menentukan keinginan dewa. Pertunjukkan Sumo digambarkan dengan dewa yang sedang bertanding, namun dewa hanya dapat diwujudkan dalam tubuh Sumo yang menang. 
Di dalam Nihon Shoki dan Kojiki, dituliskan Sumo menjadi bagian praktik kepercayaan Shinto.

Pada bagian awal iklan, gambar adegan menunjukkan bahwa seorang Sumo melakukan gerakan mengatupkan telapak tangan menghilangkan serbuk garam yang ada di tangan, sebagai bagian dari ritual Harai. Pratiwi (2017:174) menyebutkan bahwa dalam agama Shinto, ritual Harai digunakan untuk membersihkan atau menyucikan diri dari kekotoran. Keseharian masyarakat Jepang acapkali menerapkan Harai secara sederhana terjadi sebelum memasuki kuil untuk berdoa.

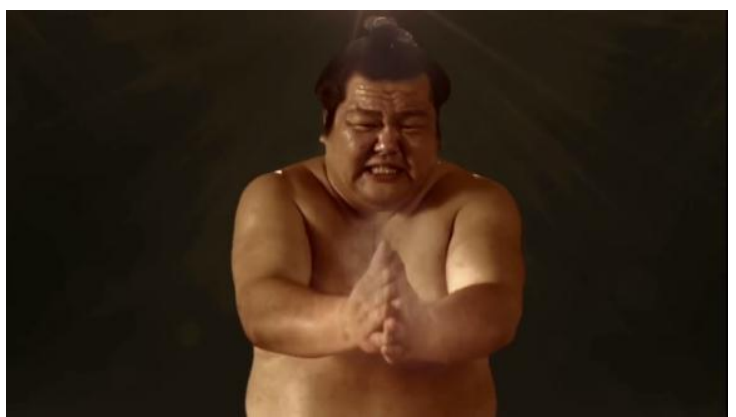

Gambar 1. Seorang pegulat Sumo sedang mengatupkan telapak tangan $(00.01)$

Sumber: youtube.com

Wendri (2013:26) menuliskan ritual lain yang umumnya dilakukan oleh Sumo adalah menaburkan garam ke empat arah (Timur, Barat, Selatan, dna Utara) sembari menghentakan kakinya berulang-ulang. Hal ini dipercaya dapat menghidupkan roh tanah demi hasil tani yang subut. Dapat diidentifikasi pula bahwa tampilnya pegulat Sumo dalam iklan menjadi representasi budaya Jepang yang menjadi kesatuan dengan produk rokok FORTE. Selain itu, instrumen alat musik kato mendominasi iringan pembuka iklan rokok FORTE ini juga memperkuat representasi tersebut.

Gambar di atas menjadi penanda bahwa olah raga Sumo tidak terlepas dari tradisi dan ritual Shinto yang menjadi latar belakang gerakannya. Budaya Jepang yang sarat akan ritual tradisi keyakinan dari jaman kuno sangat mempengaruhi kehidupan masyarakat Jepang hingga sekarang.

Menurut studi yang dilakukan oleh Hofstede (Hofstede, 2010: 59), yang tertera dalam tabel power distance index, negara Jepang sendiri menempati posisi 49-50 dengan index 54 sejajar dengan negara Canada dan Quebec. Dari index tersebut dapat diidentifikasi bahwa negara Jepang tidak tergolong dalam kategori power distance index menengah. Bila dibandingkan dengan negara sejawat seperti Malaysia, Filipina, China dengan kategori large power distance cenderung menggunakan hubungan kekuasaan yang lebih otokratis dan paternalistik. Meskipun demikian (Jepang bukan dalam kategori large/high power distance), hal ini pun tidak tampak secara eksplisit dalam iklan rokok FORTE tersebut.

Dalam dimensi maskulinitas vs femininitas, penelitian Hofstede (Hofstede, 2010: 141), negara Jepang berada di posisi atau ranking nomor 2 di bawah negara Slovakia yang berada di nomor 1 . Hal ini sejalan dengan apa yang menjadi latar belakang olahraga gulat Sumo secara khusus budaya Jepang bila ditelisik dari sejarah kekaisarannya. Maskulinitas mendominasi politik yang berlangsung di sejarah kekaisaran Jepang, bahkan hingga era moderen sekarang. Menurut studi, sebagai "mesin" penggerak ekonomi Jepang, sosok laki-laki (ayah) di Jepang tumbuh dalam budaya yang tidak memiliki sensitivitas terhadap urusan domestik dan anak. Nilai-nilai patriarki yang dikonstruksi oleh pemerintah Jepang dari zaman Edo ini diinternalisasi masyarakat dan diyakini dalam tradisi dan kesehariaan mereka (Widarahesty, 2018:63).

Terkait dimensi yang lain yaitu individualisme vs kolektivisme, Hofstede menyatakan bahwa negara Jepang memiliki tingkat kolektivisme yang tinggi. Meskipun demikian di beberapa era tidak jarang, individualisme 'merangkak' masuk ke berbagai lini kehidupan masyarakat Jepang. Bila ditelisik dari sejarahnya, individualisme sendiri di Jepang mulai dikenal pada masa 20 tahun setelah Restorasi Meiji (menjelang akhir 1900) yang oleh Uchimura Kanzo, disebut sebagai dekade revolusi spiritual. Akan tetapi, paham ini belum dapat menggeser paham kolektif yang dianut masyarakat Jepang. Individu tidak dianggap sebagai entitas yang independen. Karena entitasnya tidak diakui, suara individu tidak dapat dikedepankan. Malah, kepentingannya harus dikorbankan untuk kepentingan kolektif di mana dia berada, dan kepentingan kolektif diakui sebagai hal 
yang utama (Takano, 2008: 9). Masyarakat tradisional Jepang beranggapan bahwa kewajiban sosial dapat dipenuhi dengan tindakan sukarela sebagai wujud kesetiakawanan dan kebajikan. Orang yang mengutamakan kepentingan kelompok dituntut untuk menjaga keharmonisan kelompoknya dengan mengorbankan kepentingan atau keinginan pribadinya. Orang yang merusak keharmonisan kelompok, akan dikeluarkan (Takano, 2008: 9). Keharmonisan ini akan menjamin kelangsungan hirarki. Menurut Takano, paham negara militer adalah perwujudan dari paham kolektif yang dianut orang Jepang, dan merupakan kajian politik dan budaya Jepang yang mendominasi setelah perang berakhir (Takano, 2008: 11). Wujud paham kolektif dapat terlihat pada kepatuhan individu dalam mengikuti tradisi, termasuk di dalamnya menghormati kaisar, bersembahyang dan memberi hormat kepada patung dewa di kuil Shinto, hingga bakti bela negara dengan ikut dalam perang. Menurut Uchimura Kanzo, sejak Restorasi Meiji (1868) hingga masa sebelum PD II, pikiran yang berpusat pada negara (state-centric) sangat berakar kuat. Kata Okami yang berarti 'dewa' yang menandai pemerintah atau pihak berkuasa memiliki arti "mereka yang di atas" dan kata Ooyakeyang pada awalnya merujuk pada rumah tangga kaisar, masih memiliki konotasi kuat yang merujuk pada "pihak pemerintah". Pikiran akan "mengorbankan diri untuk kepentingan dan melayani publik" atau messhi hookoo dan "hormat kepada otoritas" atau kanson hookoo menjadi sikap yang dituntut dari setiap orang.

Bila ditelisik lebih dalam, dasar loyalitas tersebut dipengaruhi oleh keyakinan Konfusius dan Buddhisme yang tumbuh subur di masyarakat Jepang. Buddhisme memberi semangat bagi tingkah laku orang Jepang yang selalu ingin mencapai kesempurnaan. Semangat prajurit kekaisaran (bushido) yaitu semangat yang patuh kepada komandan dan berani mati demi membela kehormatan, yang kemudian diberlakukan ke dalam semangat patuh pada pimpinan dalam bisnis serta berani berkorban demi kepentingan perusahaan. Konfusianisme memberikan apa yang disebut dengan etos kerja yaitu; rajin, jujur, dan hemat (Ayu, 2012: 268).
Gerakan yang dilakukan seorang Sumo tidak luput dari ritual dalam rangka tradisi penyembahan terhadap dewa Shinto. Agama Shinto sangat mementingkan ritus-ritus dan memberikan nilai sangat tinggi terhadap ritus yang sangat mistis. Menurut agama Shinto, watak manusia pada dasarnya adalah baik dan bersih. Adapun jelek dan kotor adalah pertumbuhan kedua, dan merupakan keadaan negatif yang harus dihilangkan melalui upacara pensucian (Harai). Karena itu agama Shinto sering dikatakan sebagai agama yang dimulai dengan dengan pensucian dan diakhiri dengan pensucian. Upacara pensucian (Harai) tersebut senantiasa dilakukan mendahului pelaksanaan upacara-upacara yang lain dalam agama Shinto. Dalam kepercayaan agama Shinto, mandinya Dewa Izanagi merupakan awal dari ritual Harai yang merupakan ritual pensucian diri (Afrianti, 2018:180). Ritus-ritus yang dilakukan dalam agama Shinto terutama adalah untuk memuja dewi Matahari (Ameterasu Omikami) yang dikaitkan dengan kemakmuran dan kesejahteraan serta kemajuan dalam bidang pertanian (beras), yang dilakukan rakyat Jepang pada Bulan Juli dan Agustus di atas gunung Fuji. (Mulyadi, 2017: 18)

Dalam gerakan pegulat Sumo, tradisi melempar garam juga dilakukan karena dipercaya dapat mensucikan ring pertandingan, Tradisi ini memang sama seperti ritual Harai yang digunakan untuk memurnikan kuil-kuil Shinto di Jepang. Meski sering diterjemahkan "pemurnian", Harai benar-benar sebuah eksorsisme yang dipercaya mengusir roh jahat. Bahkan tradisi melempar garam juga sering dilakukan warga Jepang ketika pulang dari sebuah pemakaman dimana sebelum mereka memasuki rumah mereka akan menaburkan garam ketubuhnya atau dilemparkan oleh anggota keluarga yang menunggu dirumah.

Dalam tataran dimensi Long Term versus Short Term Orientation, penampilan pegulat Sumo dalam iklan rokok Forte menunjukkan dimensi kategori short term orientation karena nilai dipromosikan terkait dengan masa lalu dan sekarang, termasuk kestabilan, menghormati tradisi. Nilai tradisi Shinto yang melekat dalam olahraga Sumo turut melatarbelakangi iklan rokok Forte. Namun, banyak ritual mengalami simplifikasi 
dengan tidak ditampilkan dalam adegan seperti halnya ritual membuang garam sebagai penanda pengusiran roh jahat (Harai) yang selalu dilakukan oleh pegulat Sumo sebelum bergulat dengan lawan. Mengacu pada definisi simplifikasi, yang mana simplifikasi juga dapat diartikan membuat sesuatu yang sulit dipahami menjadi mudah untuk dipahami (Kurniawati, 2016:49), maka adegan olahraga sumo yang ditampilkan secara tidak menyeluruh, menjadi indikasi tujuan ritual sumo secara khusus dan iklan rokok Forte secara umum dapat lebih mudah dipahami.

Ritual yang dilakukan pegulat Sumo sebelum bergulat dengan lawan, pengusiran roh jahat (Harai), termasuk kuda-kuda shiko dachi yang dilakukan, gerakan membanting lawan, gerakan membuang bangku, menjadi bagian dalam dimensi kategori short term orientation.

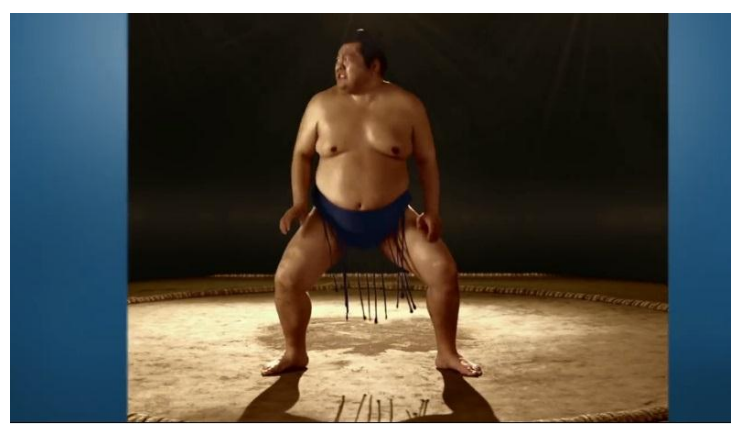

Gambar 2. Frame muncul dan bergerak mendekati pegulat Sumo

Sumber: youtube.com

Dalam gambar tersebut di atas tampak jelas frame muncul mendistorsi gambar. Disini frame berlaku seolah hidup dan mempengaruhi tindakan pegulat Sumo. Namun yang menjadi perhatian disini adalah gerakan kuda-kuda pegulat Sumo dalam adegan iklan tersebut.

Asai Shotokan Association International menulis artikel tentang kuda-kuda shiko dachi yang sering dilakukan oleh pegulat Sumo dalam situs asaikarate.com, bahwa sikap paling populer dalam Sumo disebut shiko dachi dimana seseorang dapat mengambil posisi jongkok yang sangat dalam. Bahkan, shiko dachi sangat populer di Jepang karena banyak pelatih atletik percaya ini adalah sikap terbaik untuk aktivitas atletik mereka. Kudakuda merupakan elemen penting pada olahraga manapun. Dari berbagai macam bentuk kudakuda, Shiko dachi disebut sebagai kuda-kuda persegi empat (Purba, 2015:59). Ada dua manfaat utama kuda-kuda shiko dachi, salah satunya adalah pelatihan otot-otot dalam yang menghubungkan paha dengan panggul. Melatih otot-otot ini tidak mudah tetapi sangat penting untuk karate olah raga lain termasuk Sumo. Latihan otot bagian dalam tidak dapat dimaksimalkan dengan teknik kuda-kuda yang lain. Manfaat kedua dari shiko dachi adalah mobilitasnya. Pergerakan kuda-kuda shiko dachi tidak hanya ke samping (bolak-balik) tetapi juga ke depan dengan cara yang menarik. Ketika tubuh bergeser terlepas dari bergerak ke kiri atau kanan, kaki secara alami akan terbuka.

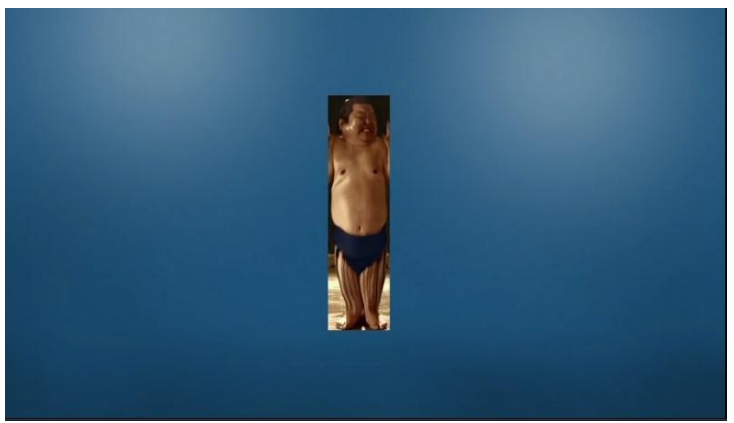

Gambar 3. Tubuh pegulat Sumo terdistorsi oleh himpitan frame

Sumber: youtube.com

Distorsi tubuh oleh frame tersebut yang pertama frame tersebut seolah hidup, yang kedua tubuh manusia seolah bisa terpengaruh dan beradaptasi secara cepat menyesuaikan ruang (distorsi) dalam waktu yang cepat. Namun demikian, frame tersebut menjadi informasi awal sebuah informasi utama berikutnya.

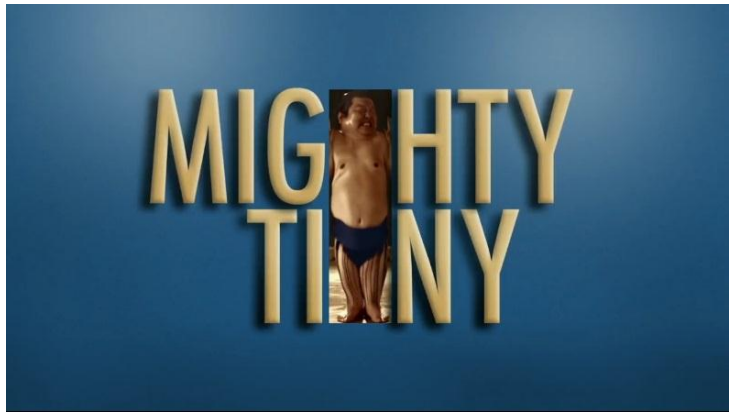

Gambar 4. Tubuh pegulat Sumo yang terdistorsi menjadi bagian dari tulisan "mighty tiny".

Sumber: youtube.com 
Tampak dari gambar di atas, tubuh pegulat Sumo yang terdistorsi tersebut menjadi huruf "i" dari tulisan MIGHTY TINY. Adapun slogan ini sejalan dengan slogan produk rokok FORTE dimana bila diartikan secara Bahasa Indonesia akan berarti "Kecil namun Kuat". Alasan dasar mengapa Forte menggunakan slogan tersebut bisa dilihat dari ukuran batang yang cenderung slim dan kecil.

Sosok pegulat Sumo sebagai bagian olahraga beladiri sekaligus budaya Jepang telah bertransformasi dari nilai budaya kuno dan representasi mitologi dewa menjadi ikon kompetisi serta agen komoditas, dalam hal ini sebagai sarana teks komunikatif iklan produk rokok Forte.

Berkembangnya atraksi olahraga Sumo sebagai kompetisi, komoditas pariwisata, dengan peran serta media, menjadikan Sumo sebagai ikon budaya bertaraf internasional. Bahkan, tidak hanya atraksinya, pegulat Sumo sendiri berkembang dan semakin dikenal di luar negara Jepang. Penelitian yang dilakukan Eiji Yamamura, bahwa sejak tahun 1970-an, semakin banyak orang asing memasuki pasar tenaga kerja Sumo, menjadikan Sumo sebagai olahraga bertingkat internasional. Bahkan pegulat domestik negara Jepang berusaha meningkatkan modal mereka dengan meningkatkan berat dan massa tubuh mereka untuk menandingi pegulat Sumo seperti yang lahir di Amerika yang mana memiliki keunggulan fisik dibanding pegulat domestik (Yamamura, 2013:16).

Hal ini sejalan dengan dimensi Hofstede yang lain yaitu dimensi budaya penghindaran ketidakpastian rendah (low uncertainty avoidance) dimana sebagai pelaku budaya, masyarakat Jepang menerima dan merasa nyaman dalam situasi yang tidak terstruktur atau lingkungan yang kerap kali mengalami perubahan. Transformasi ikon Sumo dari ritual menjadi olahraga moderen serta peran media, menjadi dasar ikon Sumo dapat digunakan sebagai komoditas, agen, sekaligus teks komunikasi dalam iklan produk. Terlepas dari upaya pesan "kecil namun kuat" dengan menghadirkan distorsi gambar Sumo yang terjepit grafis dan menjadi huruf I dalam teks MIGHTY TINY, transformasi ritual Sumo menjadi teks iklan adalah bagian penting dari penerimaan masyarakat Jepang terhadap perubahan.

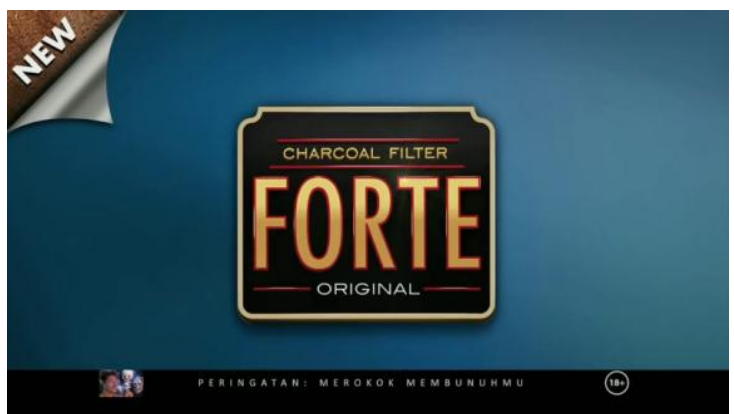

Gambar 5. Informasi produk rokok FORTE.

Sumber: youtube.com

Elemen grafis dalam visualisasi iklan tersebut sejalan dengan kemasan produk rokok FORTE dimana kemasan rokok ini menggunakan basis warna biru tua, jingga, dan putih. Bagian depan dan belakang kemasan terdapat semacam emblem logo yang terdiri dari setengah lingkaran, trapesium, dan rounded rectangle yang tergabung menjadi sebuah emblem. Emblem logo tersebut memiliki outline berwarna kuning kejinggaan dan memiliki bagian dalam berwarna hitam.

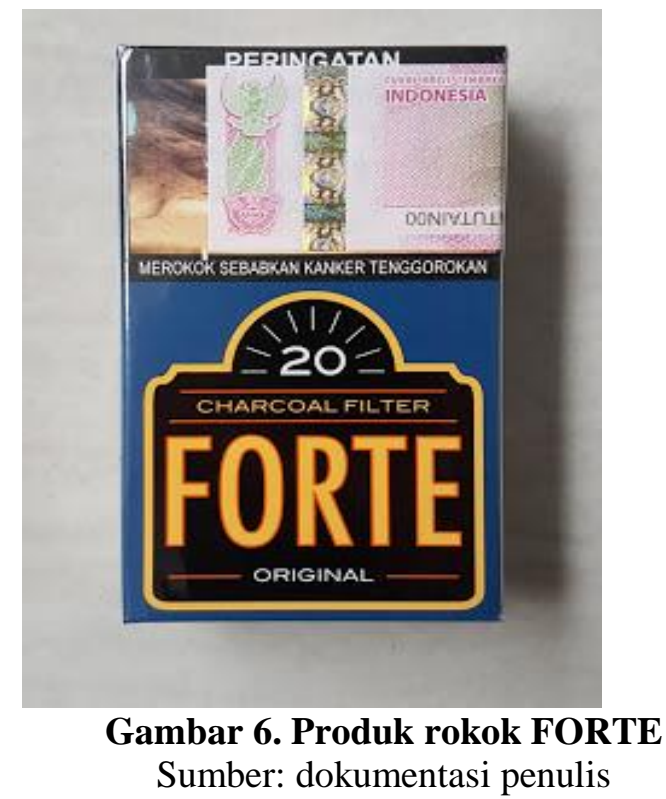

Terdapat tulisan 20 dengan adanya persegi panjang berwarna putih yang berjumlah 9, dimana 9 persegi panjang tersebut mengitari layaknya gambar matahari. Sebagaimana negara Jepang yang lekat dengan identitas sebagai negeri matahari, karena keyakinan Shinto yang memberi penghormatan khusus kepada dewi matahari. Shinto mengandung kepercayaan bahwa 
kepulauan dan bangsa Jepang bersumber pada Dewi Matahari Amaterasu Omikami yang merupakan leluhur Tenno Heika (Syahraeni, 2017:84). Terdapat pula tulisan CHARCOAL FILTER dengan adanya garis di bagian atas dan bawah menggunakan warna jingga, dimana tulisan CHARCOAL FILTER tersebut menggunakan warna jingga kekuningan. Terdapat tulisan FORTE dengan adanya efek emboss, dengan warna outline tulisan berwarna jingga dan tulisan dalam menggunakan warna jingga kekuningan. Di bagian bawah tulisan FORTE terdapat tulisan ORIGINAL yang menandakan varian rasa dari Forte, dengan letak tulisan berada diantara dua garis berwarna jingga. Bagian samping kanan terdapat tulisan 20, dengan adanya tulisan FILTER dan CIGARETTES yang mengitari tulisan 20 yang dipisahkan dengan titik. Terdapat penjelasan fitur Tobacco-Wrapped Filter Cigarettes dengan adanya gulungan daun tembakau, dan Charcoal Filter yang ditandai dengan adanya banyak titik di bagian dalam filter. Hal yang unik terletak pada bagian kiri kemasan, dimana peletakan tulisan SPM berada di bagian atas barcode. Di bagian atas terdapat tulisan FORTE yang sama dengan bagian depan dan belakang kemasan, serta ORIGINAL berwarna putih. Bagian inner hinge lid dari rokok ini menggunakan warna biru tua yang sama dengan bagian luar kemasan. Produk ini memiliki kesamaan dengan Forte yang dijual di Jepang, yakni bagian inner frame yang menggunakan warna putih serta foil yang cenderung polos berwarna silver.

Meskipun terdapat perbedaan teks karena adanya proses simplifikasi ritual Harai dalam olahraga Sumo dan juga perbedaan grafis yang mendasar di antara kemasan produk dan iklan yang ditampilkan, konsumen dengan secara sadar menerima perbedaan tersebut. Hal tersebut termasuk dalam dimensi budaya Hofstede low uncertainty avoidance. Bahkan secara umum, iklan rokok dan kemasan produk seringkali berbeda penampilannya. Dan konsumen atau masyarakat menerima perubahan dan atau perbedaan tersebut.

\section{KESIMPULAN}

Seperti apa yang dikatakan oleh Yudith Martin dan Thomas Nakayamana, bahwa identitas bisa dirundingkan, bisa dibentuk kembali, diperkuat dan dijalani melalui komunikasi dengan yang lain: identitas (identitas etnis) muncul ketika pesan saling dipertukaran di antara orang-orang. Ini artinya bahwa menunjukkan identitas kita bukanlah sebuah proses yang sederhana. Tentu tidak setiap orang melihat kita sebagaimana kita melihat diri kita sendiri.

Dalam persoalan visualisasi iklan rokok FORTE dalam konsep budaya Jepang, tidak serta merta dapat ditangkap oleh audiens atau masyarakat yang menonton iklan tersebut. Konsep avowal (pengakuan) dan askripsi penting untuk membantu kita memahami bagaimana kesan dapat menimbulkan konflik (Martin \& Thomas, 2007: 158). Pengakuan sendiri dipahami sebagai proses di mana individu memerankan diri mereka sendiri sedangkan askripsi adalah proses di mana orang lain mengatribusikan identitas tertentu pada mereka. Identitas yang berbeda digunakan tergantung individu yang terlibat dalam komunikasi. Artinya bisa saja saat kita berinteraksi dengan lawan jenis, maka identitas yang muncul adalah identitas gender dan saat kita bertemu dan berinteraksi dengan orang yang berbeda etnis, identitas yang muncul adalah identitas etnis. Identitas budaya Jepang dalam hal ini pegulat Sumo diekspresikan secara komunikatif melalui core symbols, label, dan norma. Identitas pegulat Sumo ini tentunya ingin menginformasikan produk rokok FORTE ini juga berasal dari perusahaan Jepang, meskipun hal ini tidak secara eksplisit terlihat dalam visualisasi iklan. Oleh karena persoalan durasi, dimungkinkan iklan rokok Forte secara sepihak melakukan simplifikasi dengan cara pemotongan adegan pengusiran roh jahat (Harai), yang menjadi bagian dari ritual Sumo yang filosofis. Namun, bila mengacu pada upaya penyederhanaan (simplifikasi), pemotongan adegan ritual sumo yang kompleks dilakukan pihak pengiklan agar konten dapat lebih mudah dipahami. Hal ini tentunya disayangkan mengingat Sumo dan segala ritualnya sangat kaya akan makna dan filosofi keyakinan yang melekat dalam tradisi dan budaya masyarakat Jepang. Ikon Sumo 
sebagai penanda teks komunikatif iklan produk rokok Forte dengan hanya sedikit ditampilkan ritual gerakan pegulat Sumo, bahkan terdistorsi oleh grafis imajiner dalam iklan, adalah sebuah teks bebas di luar realitas budaya dan ritual pegulat Sumo sesungguhnya. Yang menarik pula dari visualisasi iklan rokok FORTE ini adalah jika tidak terdapat grafis tulisan "peringatan: merokok membunuhmu" dan gambar perokok, maka penanaman informasi kepada masyarakat tidak lebih dari elemen visual saja tanpa tahu bahwa itu adalah iklan rokok. Grafis tulisan peringatan tersebut di atas yang justru menekankan informasi tentang produk rokok (yang baru). Kreatifitas kemasan iklan produk rokok FORTE ini bisa menjadi tren baru dalam media promosi rokok, tanpa harus menampilkan wujud rokok, dan justru dengan memanfaatkan larangan yang dibuat oleh pemerintah menurut regulasi undang-undang penyiaran yang berlaku.

\section{DAFTAR PUSTAKA}

Agger, Ben. 2006. Teori Sosial Kritis: Kritik, Penerapan dan Implikasinya (terj) Yogyakarta: Pustaka Pelajar.

Cuyler, P. L. 1979. Sumo: From Rite to Sport. Tokyo: John Weatherhill, Inc.

Hofstede, Geert. Gert Jan Hofstede, Michael Minkov. 2010. Cultures and Organizations: Software of the Mind. New York: McGraw Hill.

Martin, Judith dan Thomas K. Nakayama. 2007. Intercultural Communication in Contexts. New York: Mc Graw Hill International.

Mulyana, Deddy. 2007. Pengantar Ilmu Komunikasi. Bandung: PT. Remaja Rosdakarya.

Purba. Amir, dkk. 2006. Pengantar Ilmu Komunikasi. Medan: Pustaka Bangsa Press.

Takano, Yotaro. 2008. Kesalahpahaman tentang Kolektivisme. Tokyo: Shinyosha.
Williamson, Judith. 2007. DECODING ADVERTISEMENTS: Membedah Ideologi dan Makna dalam Periklanan. Yogyakarta: Jalasutra.

Jurnal

Afrianti, Muflikhatun. Dewi Izanami dan Dewa Izanagi dalam Agama Shinto Jepang (Studi Semiotik dalam Film Noragami Aragoto). Jurnal Religi, Vol. XIV, No. 2, JuliDesember 2018.

Ayu, Rindu dan Yusy Widarahesty. Perkembangan Peran dan Fungsi Zaibatsu (Kongsi Dagang) Dalam Bidang Politik dan Pemerintahan Jepang Sebelum PD II Sampai Pasca PD II. Jurnal Al-Azhar Indonesia Seri Pranata Sosial, Vol. 1, No. 4, September 2012.

Cahyo, Rizki Dwi, Masilva Raynox Mael. Konsep Sosial Budaya Hubungan Manusia dalam Pembentukan Kata Majemuk Bahasa Jepang. Paramasastra: Jurnal Ilmiah Bahasa, Sastra, dan Pembelajarannya, Vol.4 No.2 September 2017.

Mudji, Hartono. Wanita Jepang dalam Perspektif Historis. MOZAIK: Jurnal IlmuIlmu Sosial dan Humaniora, Vol.2 No.1, 2007.

Mulyadi, Budi. Konsep Agama dalam Kehidupan Masyarakat Jepang. Izumi, Vol. 6, No 1, 2017.

Kurniawati, Nike Esti. Seloka: Jurnal Pendidikan Bahasa dan Sastra Indonesia, Vol. 5, No. 1, 2016.

Pratiwi, Citra Ayu. Harai: Telaah Konsep Religi Koentjaraningrat. Japanology, Vol. 5, No.2, 2017.

Purba, Pangondian Hotliber. Pembelajaran Kihon Dalam Olahraga Beladiri Karate. Jurnal UNIMED, Vol. 14 No. 2, Juli Desember 2015: 57-64

Sari, Ida Ayu Laksmita. Maskulinitas Tokoh Taro dalam Mukashi Banashi. Aksara, Vol.28 No.1 Juni 2016 
Suliyati, Titiek. Bushido Pada Masyarakat Jepang: Masa Lalu dan Masa Kini. Izumi Vol. 1 No.1. Juni 2013

Syaraeni, Andi. Islam di Jepang. Jurnal Rihlah Vol. 5 No. 2/2017

Tanudjaja, Bing Bedjo. 2016. Kreatifitas Pembuatan Iklan Produk Rokok Di Indonesia Jurnal Nirmana Vol. 04, No.1, Januari 2002

Wendri, I Gusti Made, Ni Putu Somawati, Ni Made Sudarmini. Sikap Dogmatis Wisatawan Jepang terhadap Paket Trial Yoga di Bagus Jati Health \& Well Being Retreat. Soshum Jurnal Sosial \& Humaniora, Vol.3, No.1 Maret 2013

Widarahesty, Yusy. Fathering Japan": Diskursus Alternatif Dalam Hegemoni Ketidaksetaraan Gender Di Jepang. Jurnal Kajian Wilayah, Vol. 9, No.1, 2018

Yamamura, Eiji. Is body mass human capital in sports? Outcome of globalization of Sumo wrestling and generation of human capital in 